\title{
The Spiritual Values of Islamic Economics in Tasawuf Modern: Scrutinizing the Work of Haji Abdul Malik Karim Amrullah (Hamka)
}

\author{
Rahmad Hakim ${ }^{a}$, Ahmad Fanani ${ }^{b}$ \\ ${ }^{a}$ Faculty of Islamic Studies, University of Muhammadiyah Malang, Indonesia \\ ${ }^{b}$ Sultan Omar 'Ali Saefuddien Centre for Islamic Studies, Universiti Brunei Darussalam, Brunei Darussalam \\ Corresponding email: rahmadhakim@umm.ac.id \\ http://dx.doi.org/10.22515/shirkah.v6i1.391
}

\begin{tabular}{|c|c|}
\hline ARTICLE INFO & ABSTRACT \\
\hline $\begin{array}{l}\text { Keywords: } \\
\text { Haji Abdul Malik Karim } \\
\text { Amrullah; Islamic Economics } \\
\text { Ethics; Spiritual Values; Sufism; } \\
\text { Tasawuf Modern } \\
\text { Article history: } \\
\text { Received: } 27 \text { February } 2021 \\
\text { Revised: } 31 \text { March } 2021 \\
\text { Accepted: } 02 \text { April } 2021 \\
\text { Available online: } 11 \text { April } 2021 \\
\text { To cite in APA style: } \\
\text { Hakim, R., \& Fanani, A. (2021). } \\
\text { The Spiritual Values of Islamic } \\
\text { Economics in Tasawuf Modern: } \\
\text { Scrutinizing the Work of Haji } \\
\text { Abdul Malik Karim Amrullah } \\
\text { (Hamka). Shirkah: Journal of } \\
\text { Economics and Business, 6(1), 83- } \\
\text { 100. }\end{array}$ & $\begin{array}{l}\text { Islamic economics has existed since the start of Islamic } \\
\text { civilization. However, Islamic economic thoughts established } \\
\text { by Indonesian scholars are limited. This exploratory research } \\
\text { was carried out to determine the spiritual values of Islamic } \\
\text { economics on Hamka's works entitled Tasawuf Modern. } \\
\text { Primary and secondary data were collected from Hamka's } \\
\text { works entitled Tasawuf Modern and from several papers or } \\
\text { books that are relevant to the focus of the research. The data } \\
\text { collected were analyzed by combining topics relevant to } \\
\text { Islamic economics in modern Sufism and other secondary } \\
\text { sources. Content analysis was used for data analysis. The } \\
\text { results of this study revealed that, according to Hamka, the } \\
\text { richest people are those that need the least. The true wealth lies } \\
\text { in the contentment of the soul (qana'ah). Good wealth } \\
\text { represents virtue and prohibiton for extravagancy and } \\
\text { excessive consumerism. Further, humans need to be in } \\
\text { between to carry out good deeds. The results of this study } \\
\text { contribute to enriching the discourse of Islamic economic } \\
\text { thought, especially in Islamic economic ethics and the role of } \\
\text { ethics in business. }\end{array}$ \\
\hline
\end{tabular}

This work is licensed under a Creative Commons Attribution-NonCommercial 4.0 International License.

\section{Introduction}

Islamic economy is a system based on Islamic ethical values (Aliyu \& Aini, 2017; Haniff et al., 2018; Nawaz, 2019; Sahin, 2018). Despite different conceptions and points of emphasis among Muslim economists in this field, they agree that normative and ethical values of Islam are inseparable from the realm of the discipline of economics (Hafas et al., 2020; Hasan, 2020). Islamic economics is a study of the ummah's (Muslim community) economic behavior, which is a representation of modern society, based on ethical-normative values such as monotheism, justice, freedom, and responsibility 
(Naqvi, 2003). According to Chapra, Islamic economics is a branch of Science that encourages the realization of human welfare through the allocation and distribution of limited resources in line with the preservation of the maqāsid sharia values without limiting individual freedom, thereby creating ecological balance and sustainable macroeconomic growth in line with the value of family solidarity, social, and community morals (Al Haq \& Wahab, 2019; Chapra, 2008; Shinkafi \& Ali, 2017). Khan stated that the Islamic economy is an economic system that aims to create human welfare (human Falah) by carrying out natural resource organizations on the basis of togetherness (cooperation) and participation (Khan, 1984). In line with previous definitions, Siddiqi describes that the Islamic economy is a social activity for the ummah to achieve falah, such as the welfare of the world and the hereafter (Jan, et al., 2015).

The history of Islamic economics started with the arrival of Islam (Alamad, 2017; Hajjar \& Habib, 2019). Therefore, in the historical discourse, its values rest on historical portraits and thoughts of scholars and intellectuals in the Arab world from the Prophet Muhammad's phase to the Ottoman dynasty (Hakim, 2018). Historically, Islamic economics has existed since civilization. It started in the State of Medina and was led directly by the Prophet Muhammad, through the Umayyad, till it reached a golden phase of the Abbasid, with the presence of prominent Islamic economic prolific figures, such as Abu Yusuf, Abu 'Ubaid, Yahya Ibn 'Adam, Imam al-Mawardi, Imam al-Ghazali to Ibn Khaldun (Tellier, 2019; Watkins, 2020).

However, the opinions of these figures are often different from what occurs in the Indonesian context. Hence, such brilliant thoughts are often difficult to apply over time, particularly with different thoughts of taxation in Islam (Hakim, 2016; Tahir, 2017). Thus, it is necessary to provide an in-depth analysis of the history of Islamic economic thought that has been carried out by Indonesian scholars and intellectuals, such as Haji Abdul Karim Malik Amrullah (Hamka). Hamka is an Indonesian scholar and intellectual with a number of works in the fields of literature, history, and religion associated with the interpretation of the Qur'an (Hidyayat et al., 2020; Ismail, 2017; Lukman, 2018; Zainuldin, et. al., 2018). Although he is known for his expertise in literature, history, and religion, several of Hamka's works deal with the discourses on the spiritual values of the Islamic economic (Hakim, 2018). Hamka's thoughts range from religious, political, social, legal to historical, and economic issues. The context of this current discussion is associated with the relevance of Hamka's thoughts on economic topics.

A study on Hamka's writing associated with economics had been carried out by Syarifuddin (2010). He describes that according to Hamka, usury remains haram forever and has an impact on social change in society that applies it, especially the 
friendship loss, hatred, prejudice, and exploitation of others. Regarding zakat, Abdullah, et al. (2010) explains that according to Hamka, zakat can prevent apostasy among Muslim youth who live in poverty by describing the sacrifice of the ulama (religious expert) in establishing Islamic associations to fend off Christian missionary by collecting zakat from the Muslims. Further, Md Isa \& Am (2015) expressed that Hamka strongly emphasizes Muslims to deepen the commandments of zakat with science and social awareness. He also associates the influence of knowledge about the zakat that will yield various positive implications for the ummah if it is understood in line with the demand revelation.

Zulfa (2015) examined the interpretation of M. Quraish Shihab and Hamka on the verses regarding the management of orphan property in the Qur'an. It has resulted that there were similarities and differences. The similarities in the interpretation of the two lie in terms of the maintenance and development of the assets of the orphan, careful investigation or examination in managing their assets, and the time of handing over the assets to the orphans. The difference was in the interpretation of the meaning of the term "rushd" in Surah An-Nisa: 6. Among the differences was the age of the orphans. In addition, it questions the poor guardian who enjoyed the wealth of the orphaned children for living needs; whether he should them when he is able to pay for it, or not. According to Hamka, it is obligatory to return it, whereas M. Quraish Shihab says the opposite. On the other hand, Faiz (2016) studying Hamka's interpretation of the word "israf" in Surah al-Furqan: 67 with two meanings which are royal and careless. The meaning of the word "israf" in various forms, in general, the meaning exceeds the limit or exaggeration.

Studies related to Sufism written by Hamka have been carried out by several authors, including Almanar (1993), Ihsan (1997), Aziz (2002), and Ridjaluddin (2008) showing that Hamka believes that a person can still keep in touch with the world to earn wealth, to have family, to serve people, to have the position, and to hold any worldly profession, and yet remains a true devoted Sufi. Ulfah (2017) states that according to Hamka, Sufism is not only defined as a solitary spirit, away from the hedonism, instead actively working is a must. If a Muslim with several of these professions can apply Islamic values, he can be called a Sufi in the modern age. Naldo (2016) explains that Hamka criticizes the view of materialism by stating that God is a being who controls the complexity of this nature. God is both transcendent and immanent. God has nothing in common with His Creation. In line with this, Hakim (2018) shows that according to Hamka, ownership of property belongs to God; humans are only managers of these assets. According to him, there are three principles of Islamic economics: justice, freedom of action, and freedom.

According to Haris (2010), Setiani (2011), and Subhi (2012), Hamka's ethical 
thinking is a harmonious blend of religious and rational philosophy. Hamka stated that the motivation for a Muslim's moral actions is transcendental, seeking the pleasure of Allah, for the happiness of the world and the hereafter. The moral actions of a Muslim should be based on a world view of tawhid (the oneness) that goes beyond pragmatic interests. Rouf (2012) and Rouf et al. (2013) describe that Hamka's tasawuf aims at liberating humans from practices that deviate from the Islamic teachings that bring people closer to modern Sufism brought up by suggesting several approaches that are closely related to the socio-culture of Indonesian society. His realistic Sufism leads to direct involvement with the community on an ongoing basis and is of the view that Sufism is indispensable in a society.

Zaprulkhan (2013) did a comparative study on Hamka and Said Nursi's constructive critics and tasawuf. The study found that both Hamka and Said Nursi gave constructive critics and tasawuf reformation due to the factors of conditional-contextual, internal-substantial, and spiritual drought of the $20^{\text {th }}$-century Muslim society. Both two made greater attempts to do Sufism ijtihad (effort) in formulating their Sufism discourse with moderate patterns so that they could be accessed by all society levels. Thus this moderate tasawuf can play more positive functional roles for extensive contemporary society with all aspects.

In his study, Hidayat (2015) revealed that Hamka believed that the most important thing was ethics (akhlaq). Even it is one of the amazing of the Holy Qur'an which had spread Islam to the world. For Hamka, spirituality is an infinite idea inherent in humanity. To deny it means to negate the selfhood of human beings. Therefore, Sufism is the best way to present the transcendent since it becomes a necessity for human at the time of sorrow (Sutoyo, 2015). In line, Silawati (2015) found that Hamka Sufism is able to provide an understanding to overcome the spiritual crisis of modern humans and its impacts. Sufism offers the spiritual needs of modern humans.

According to Najib (2018), in contrast to the more classical Sufism emphasizes on Irfani epistemology, the modern Sufism Hamka using Bayani epistemology intertwined on the question of the cleansing of the soul and cultivate noble character. He was outlining the subject of war against lust, asceticism, qana'ah, ikhlas, and tawakkal. The modern Sufism Hamka supplemented on the basis of tauhid, unity of the God, and based on Qur'an and hadith.

Concerning the issue of spiritual values of Islamic Economics, this study proposes an in-depth analysis to determine the spiritual values of Islamic economics on Hamka's works entitled Tasawuf Modern. This study is significant with the upcoming concept of spiritual values of Islamic Economics to enrich the discourse of Islamic economic thought, especially in Islamic economic ethics and the practics of ethics in business done 
by Muslim entrepreneur. As there have been inconsistent findings creating a research gap in the precursor studies, this study tries to settle the gap. Therefore, this study aims to conduct an in-depth analysis to determine the spirit of Islamic economic values related to one of Hamka's works entitled Tasawuf Modern. Furthermore, the results of this study contribute to enriching the discourse of Islamic economic thought, especially in Islamic economic ethics and the role of ethics in business.

\section{Method}

\section{Research Design}

This study aims to conduct ah in-depth analysis to determine the spirit of Islamic economic values related to one of Hamka's works entitled Tasawuf Modern. To reach the objective, an exploratory study was carried out to delineate the discourse being studied. In the context of this study, qualitative research was employed to scrutinize the thought of Hamka on the spirit of Islamic economic values in his works entitled Tasawuf Modern. In this regard, several topics were discussed such as the essence of being rich, the classification of wealth, the wealth impact to the owners, the good and the bad of wealth, the human need for wealth, the source of wealth.

\section{Research Object and Data Sources}

This study seeks to reveal the spirit of Islamic economic values related to one of Hamka's works entitled Tasawuf Modern. This research is qualitative-descriptive. The object of this research is the value of Islamic economic ethics in the work of Hamka, Tasawuf Modern. For convenience, the authors classify data sources from primary and secondary sources (Nazir, 1988).

The primary source in this study is the authentic work of Tasawuf Modern written by Hamka referring to the mapping of scientific disciplines and the content of some of his works of 118 books and several unpublished articles (Hamka, 1983). The secondary source in this research is the researches studying Hamka and his works. Online and offline instruments were used. The online instrument was google scholar and open journal access owned by the university. Meanwhile, the offline instruments were a number of libraries to look for research or works related to Hamka and his works.

\section{Instrumentation and Data Collection}

The research instrument in qualitative research is the researcher himself. Increasing understanding of research methods is important for researchers to maintain the validity of data collected in order to achieve research objectives. According to Moleong (2014), researchers as research instruments are one of the characteristics of qualitative research. Documentation was done to examine documents related to the object of research including text, photos, stories, pictures, etc. (Raco, 2003). The documentation was done based on considerations (Creswel, 2014) that the object examined in this study was the 
spirit of Islamic economic values related to one of Hamka's works entitled Tasawuf Modern.

\section{Data Analysis}

The data analysis in this study was content data analysis (Bungin, 2003) done manually without using particular coding software. It began with finding certain symbols, in this case, to carry out an inventory of texts relevant to the research topic of the values of Islamic economic in Hamka's work entitled Tasawuf Modern. After the text has been inventoried, data classification was carried out based on symbols to classify Islamic economic values in selected Hamka's work. Next was to make predictions or analyses related to the classified data.

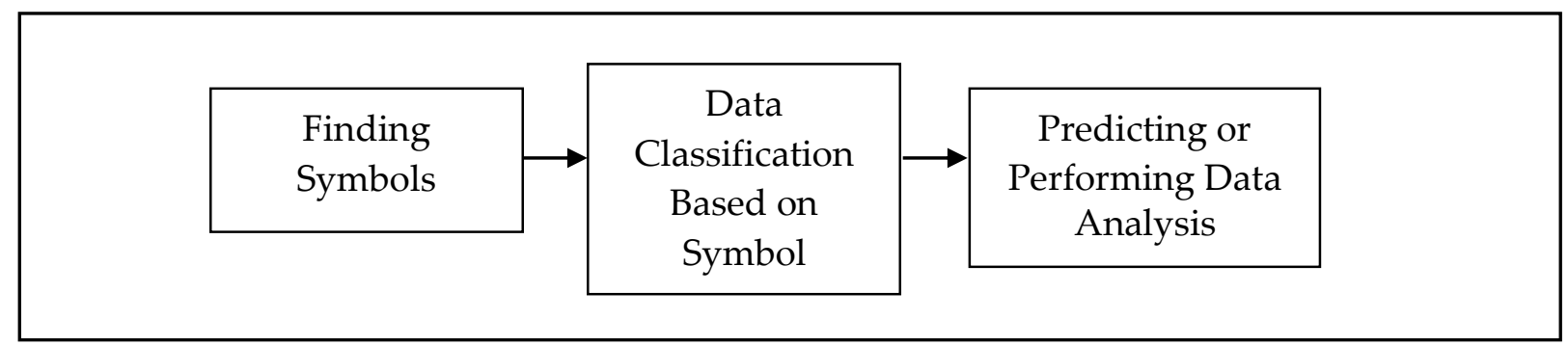

Figure 1. Content Analysis Technique Flow

\section{Results}

\section{Hamka's Idea on the Essence of Being Rich}

The richest people are those that need the least, therefore, the indicators of people's wealth and poverty are determined by their needs (hajat) and necessities for something. Those that need the least are the richest, and vice versa. Allah Almighty is the richest because He does not need anything (Hamka, 2018). In the Qur'an, it is stated that Allah is rich while humans are poor, destitute, weak, and needy beings (antumul fuqara' wa Allahu ghaniyyun hamid). Furthermore, Hamka advised that in order to reach the state of being rich, the first step is to have the nature of feeling sufficient (qana'ah) by being contended (Hamka, 2018). The second step is to have a modest nature by spending wealth on useful goods or affairs and avoiding consumerism (Hamka, 2018).

Wealth as one's personal property is intended to direct human nature and attitudes to seek, possess, and use them in the right way (Abdullah, 2004). Furthermore, the function of wealth in Islam is as a provision for worship, life support, a test of faith, support for becoming a leader, and one of life's jewels (Andiko, 2018). This is because it is a mandate that needs to be accounted for in the future before Allah SWT and is used to benefit oneself and the community (Astiraga, 2018).

Regarding wealth ownership, Rahman (1996) stated that individual and public ownership is recognized in the Islamic economic system at the same time. These two rights are not absolute, rather they are a deposit (mandate) given by God to humans. 
Hence, everyone needs to acquire wealth in the form of goods or services in a lawful manner (Akbar, 2012).

\section{Hamka's Idea on the Classification of Wealth}

In the Qur'an, wealth (al-mal) comprises food (tha'am), land (ardhun), and money (dirham). According to Andiko (2018), it also has the same meaning as qintharah, tsamarun, kanzun, khaza'in, maghanim, al-anfal, mata', al-khair, and al-turats. Hamka stated that wealth (property) is divided into two, namely true wealth (real) and pseudo wealth (not real). True wealth is obtained when people are contended with what they have and are able to accept good and bad (Hamka, 2018). Wealth is a divine blessing when multiplied, therefore, it needs to be used to encourage charity, faith, and determination to worship Allah. Wealthy people are not expected to be disappointed when their wealth decreases because everything belongs to Allah. Human love for the property is not the wealth itself because it is a gift from God meant for useful things. Therefore, people with this behavior tend to face two types of dangers, namely stingy and extravagant. They are also arrogant neglecting that humans are not absent from the trial. This pseudo nature of wealth makes a person also crave more needs (Hamka, 2018).

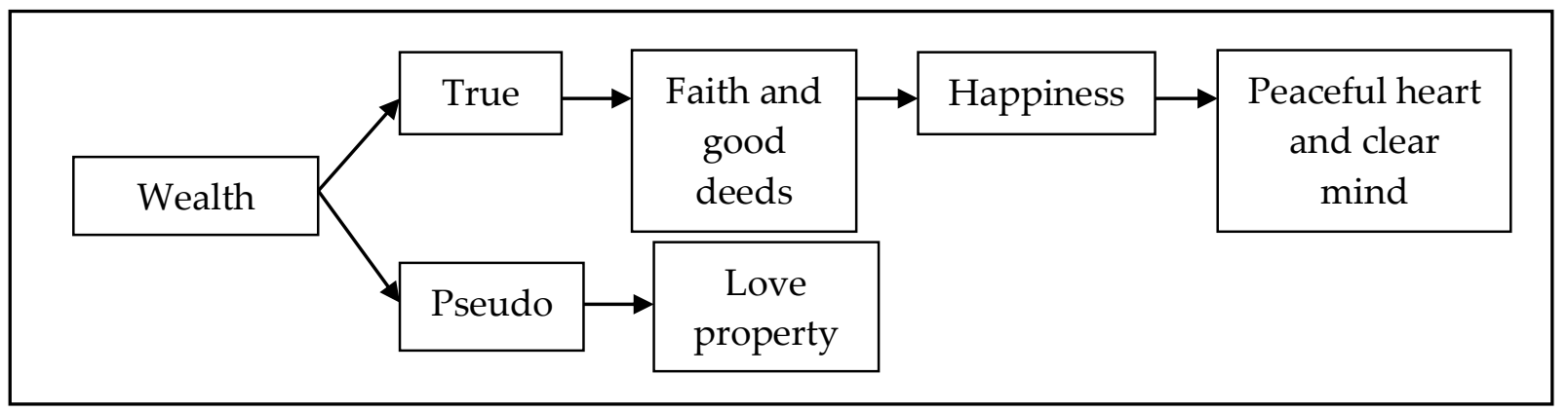

Figure 2. The Essence of Being Rich according to Hamka's View

The principle of benefit based on maqāsid sharia to protect wealth (hifdzu al-mal) is associated with the ideology that Allah is the owner of the wealth. According to asSyathibi, in the context of wealth ownership in accordance with the maqāșid sharia, a Muslim is prohibited from stealing, cheating, betraying, practicing usury, and replacing damaged goods. Therefore, wealth is maintained (hifdzu al-mal) in accordance with maqāșid sharia (Iswandi, 2014). In the context of the differences between rich and poor, each has something in common. Those that are rich and sleep on luxurious mattresses and expensive blankets have something in common with those that lay merely under the sky. Furthermore, when they are sick with fever, death is approaching, they are crowned with gold with the layered guard (Hamka, 2018).

\section{Hamka's Idea on the Wealth Impact to the Owners}

In Islam, wealth is a deposit from Allah that needs to be developed and used honestly 
for poverty alleviation. The (good) way of obtaining wealth and using them to meet needs is the Sharia's main objective (maqāṣid syarīah). Faith or devotion plays an important role since without its existence, wealth becomes meaningless towards the Sharia's objectives (Chapra, 2008).

According to Hamka, wealth makes all wishes come true. For instance, it enables masters to control their slaves, to get the poor to carry out work. A person often reaches a certain position, power, and authority due to wealth. The love for property makes humans unconsciously become its slaves (Hamka, 2018). When a property is excessively valued, it leads to losses. Wealth is considered the main goal of everything since collecting and saving represents glory, a tool to boast and exalt honor (Hamka, 2018).

The ability to put things in their place is important, and this is similar to the act of determining the fair price of everything, including property. Hamka reported that certain gold as big as a mountain laid in the middle of a large field and was not visited by humans because it was not needed. This means that less gold was more valuable than a large number while in the City. Some changes were worthless in the hands of the rich and valuable amongst the poor. The price of an object becomes high and low depending on the needs and the way it is perceived by humans. Although everything is basically classified as worthless, life does not need to be taken to the cemetery because it is needed daily (Hamka, 2018).

\section{Hamka's Idea on the Good and the Bad of Wealth}

People generally think the root of happiness is the amount of wealth. In fact, it is the other way round. This is because the more the wealth, the farther the self-awareness, the more the arrogance, the closer to inner misery. Hamka further stated that a person's true happiness does not come from his possessions, rather it lies in a peaceful heart and calm mind (Hamka, 2018). Basically, wealth (al-mal) in the view of Islamic economics belongs to Allah SWT and needs to be used by humans as a tool, and not a goal, to achieve true Falah (welfare), both in this world and in the hereafter (Rusdan, 2017).

Haq (2013) stated that in Islam, the key variable in the distribution of wealth is zakat, which minimizes the practice of usury and the inheritance system (fara'id). This is because there is a significant impact related to zakat's application in terms of reducing the income gap. Sometimes wealth is associated with the devil, regardless of the halal. Meanwhile, to obtain real happiness, the rich think that all their desires need to be fulfilled, by violating the norms of politeness, manners, and morals, regardless of the environment and social jealousy (Hamka, 2018). In fact, the assumption of egoism and greed as instincts in humans is forbidden in the Al-Qur'an (Khan, 1984).

An extravagant behavior is an example of bad wealth, which is associated with 
excessive spending through gambling, for instance winning once and losing six times. When people win once, they tend to forget their defeats. Victory is also risked at once, therefore without realizing it, people tend to become poor in the long run. The more wealth expended to satisfy lust, the greater the regret and lack of happiness. According to Hamka (2018), Allah likens those that are willing to achieve happiness by spending their wealth excessively to the act of pouring gasoline into a flame that tends to burn uncontrollably.

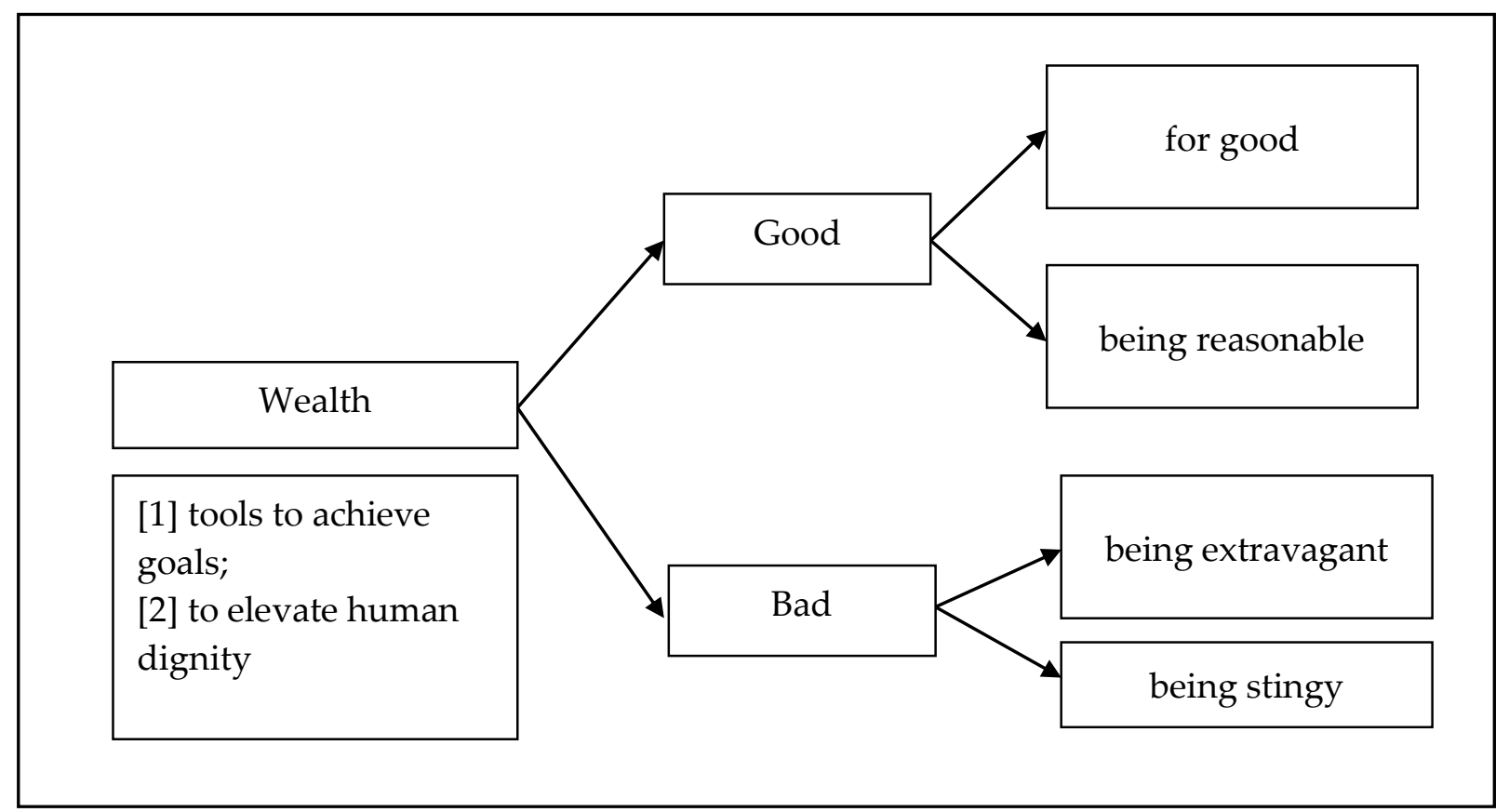

Figure 3. The Purpose of Wealth (Good and Bad)

In Al Qur'an and hadith, extravagant behavior is described in two terms, namely israf and tabdzir. Islam prohibits wastefulness, although the limits of waste in an Islamic economy are subjective (Ridwan \& Andriyanto, 2019). The scope of meaning associated with israf is much wider than tabdzir, which only displays material relation patterns, while israf includes all existing relationships. Abdurrahman (2005) stated that the material relationship is seen from a person's lifestyle in being materialistic. In Islam, consumption behavior demands a separation between wants and needs (Huda, 2006). It is in line with the Quran that the way to manage and spend wealth is by determining priority needs, based on the principle of halalan thayiban, avoiding waste and tabdzir, managing wealth for the future, allocating social spending, and the principle of simplicity (Masrur, 2018).

Islamic economics value system places al-falah as its main goal because it is physical and accompanied by inner well-being (al-shalah), worldly and spiritual pleasures, material and immaterial balance. This objective clearly shows that the essence of Islamic economics's value system is a blessing for all humans and the nature (rahmatan lil 'alamin) (Aziz, 2013). Further, El-Ghazali (1994) stated that Islam's main 
goal in the economics is to create a balance between human internal and external motivations and spiritual and material aspects to become the Creator. Ahmad and Hassan (2000), stated that the Islamic perspective in distributive justice emphasizes the humanist aspect with three important principles, namely justice ('adl), insaf and ihsan. In Islam, the merit system in sharing wealth is applied to minimizing economic and income inequality.

Hamka's opinion cites a statement of a hukama that the purpose of seeking wealth is to maintain dignity, fulfill obligations, and avoid begging and borrowing (Hamka, 2018). When people do not have enough wealth, they are not trusted. As quoted in the verse, "How wonderful it would be to gather religion and the world in someone, And how miserable it will be if you gather disbelief and poverty." Therefore, Hamka defined property as a tool used for evil or goodness depending on the owners. Therefore, one needs to be careful to avoid valuing wealth more than its true price (Hamka, 2018).

Furthermore, wealth is a means of realizing one's desires to achieve goals. It is usually useful for the last, therefore it should not be used for any purpose for which they were not intended. Wealth is expensive, however, it should not be valued more than self-respect, the glory of religion, the pleasure of Allah, and the virtuous of one's mind. In short, "Wealth for stepping stone, not titles that increase wealth" (Hamka, 2018). In this context, Hamka quoted the following verse, "The value of wealth before it is issued (infaq or spending) is like the price of sand, new wealth is valued if it changes hands".

\section{Hamka's Idea on the Human Need for Wealth}

According to Hamka, there are three pillars or principles of human needs in fulfilling life. The first is spiritual needs (al hajah an-nafsiyah), the material needs (al hajah albadaniyah), and the external needs (al hajah al-kharijiyah). The external needs deal with shelter, clothing, etc. Dinar, dirham, rupiah, and ringgit, are among the external needs in life (Hamka, 2018). The line of thought, in this case, is as stated, "Science and character form the mind, affects the inner gross body, enslaves food and drink, which in turn affects money." Therefore, the needs of food, drink, and clothing require money. The purpose of eating and drinking is for survival while waiting for death. A healthy body is necessary for mental health (Hamka, 2018). Moreover, Hamka stated that remembering Allah (dzikrullah) is advantageous. People tend to neglect dzhikrullah because of the children and property they are likely to lose. Furthermore, many people are less wealthy and lucky. However, this does not break with God (Surah Al-Munafiqun: 9), and that is why it is stated in the Qur'an, "Which of you likes to profit in business and is lucky to make sales?" (QS. As-Shaf 10-11).

In this regard, Hamka states that we have to remember the effect of vitamins on health and in mind (Hamka, 2018). When humans always remember this, it makes them 
repent for the glory of self-respect (inner soul). Wealth is only the first step, while the ultimate goal is the perfection of the soul. Therefore, the goods, money, and wealth sought are for the perfection of the soul, not for the perfection of wealth. The aim (himmah) is not just the treasure itself, and this is why Allah says, "the truth of your property and your children is slander."

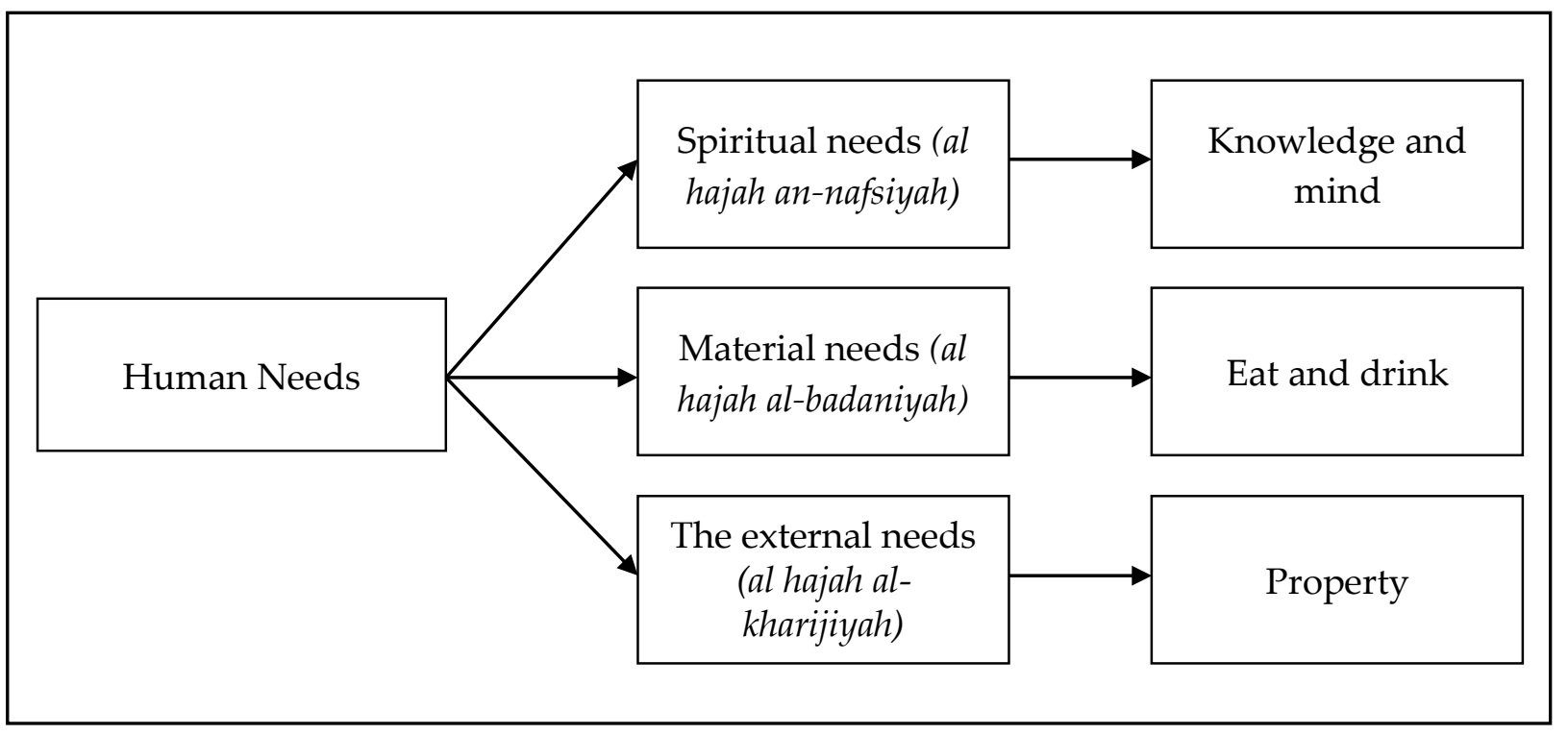

Figure 4. Human Needs for Wealth

\section{Hamka's Idea on the Source of Wealth}

According to Hamka, there are two sources of wealth, firstly from own business (livelihood) and secondly, given or inherited or received unexpectedly. Furthermore, there are several forms of effort made by humans in obtaining wealth (Hamka, 2015), namely: (a) hunting and fishing, (b) agriculture, (c) mining, (d) confiscation (war), (e) services and entrepreneurship (entrepreneur), (f) government cultivated land, (g) inheritance or will, and (h) alms. Wealth is also obtained from two sources, namely halal (lawful) and haram (forbidden). An item is termed halal when it is lawful and can be taken. However, when it is haram, desist from its usage because it tends to destroy one's character (Hamka, 2018).

After carefully determining where the wealth is obtained, the next task is determining the right place to spend it in a commendable way. Wealth is said to be commendably spent when used fairly and according to definite rules, such as providing necessary alms for children and wives and being donated for the needs of the ummah (society). Meanwhile, wealth is uncommendably spent in two forms, namely too much and too stingy. It is said to be exaggerated, assuming the shopping costs are more than the income. Therefore, it is not affordable as it ignores the need and follows lust. Destruction is often the result of being too stingy because that does not spend the wealth on necessary things (Hamka, 2018).

In life, differentiation of income (sustenance) and economic inequality is 
sunnatullah. This condition requires a system that naturally creates economic mechanisms, where the rich helps the poor, thereby decreasing economic inequality. In Islam, this is called zakat, infaq, and alms. According to Ryandono (2009), by helping and giving each other, human needs are fulfilled.

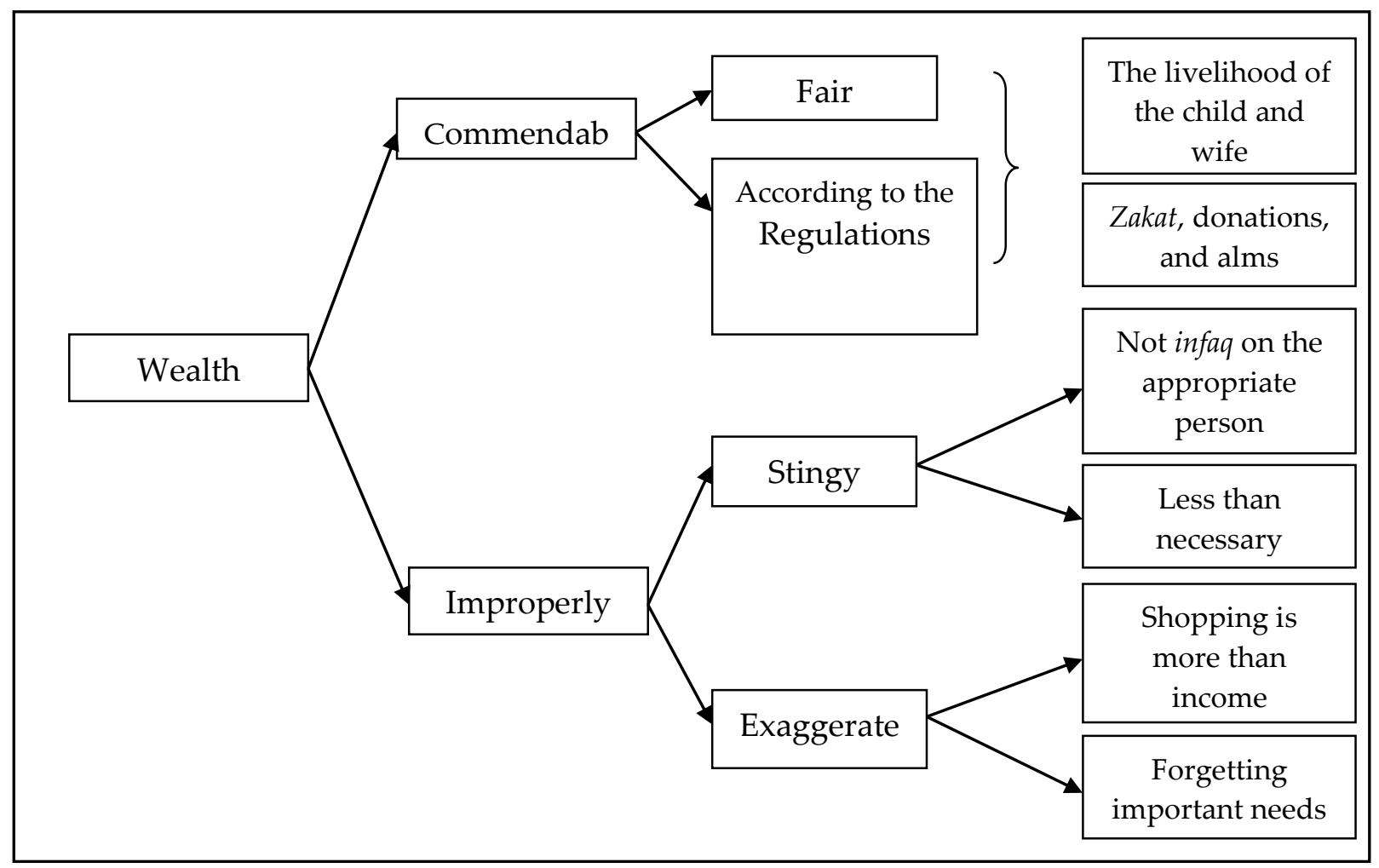

Figure 5. Hamka's View on the Wealth Distribution Concept

Further, according to Hamka, human responses in dealing with wealth are divided into three types. First, the destroyed or failed group who do not consider the hereafter. Some also remember the hereafter only for formality, as lip service. According to the Qur'an, this type of wealth is known as the devil worshiper (abdatu taghut) or the bad ever animals (syar ad-dawab) (Hamka, 2018). Second, the group that entirely turned away from the world and wealth. This is because they only focus is only remembering the purpose of worship for Allah and the Hereafter. Third, the middle group paying for the rights of the world and the hereafter to support their deeds. This is because they believe that the acts of worship are not only achieved by just sitting but by helping others. After all, good deeds are unachievable without the support of wealth. People that collect the benefits of religion and the world through wealth are permitted by Allah to be leader (khalifah) on earth. 


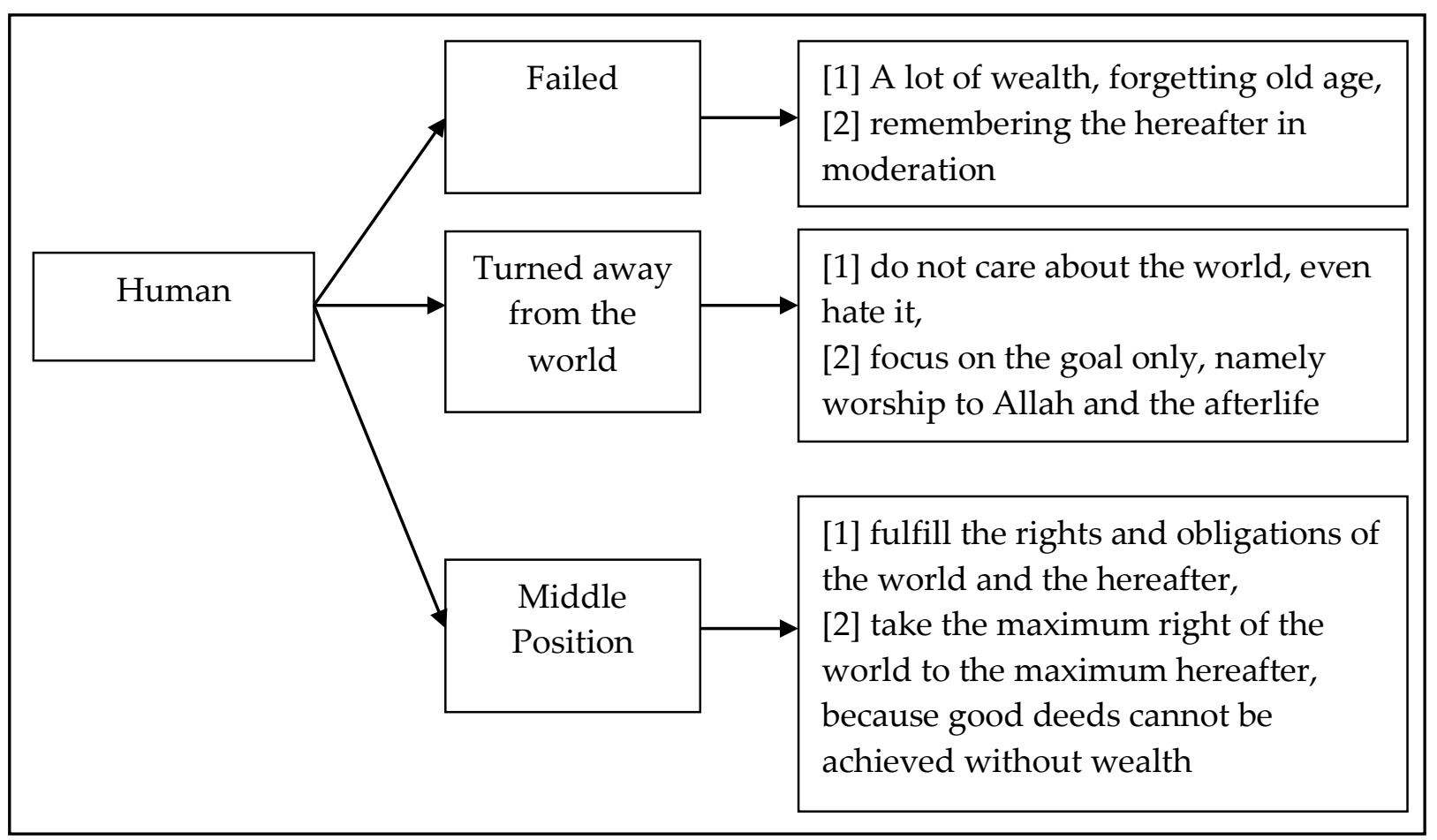

Figure 6. Human Responses to Wealth

\section{Discussion}

Hamka's contribution to Islamic economic thought is significant, as indicated from the differences in perspective in Sufism's context towards the asset. In line with Haris (2010), Setiani (2011), and Subhi (2012), the book entitled "Tasawuf Modern" recommends Muslims to work hard in order to obtain as much wealth as possible in an effort (ikhtiar) to carry out maximum virtue. Consequently, Hamka implicitly stated that a Sufi is those that work optimally to carry out maximum virtue deeds in order to obtain a significant life in the hereafter (Ulfah, 2016). Sufism is synonymous with leaving wealth and is only concerned with the problems of the hereafter (Silawati, 2015).

Conversely, Hamka's thought on the source of wealth is important to become a guide today. Due to the increasing competition and complex needs, as well as the population density in Indonesia, halal wealth is increasingly difficult to gain. It is important to choose halal wealth. However, during an emergency condition, haram can be an option. In a hadith, it is stated that looking for halal wealth is an obligation after the pillars of Islam.

Hamka stated that true wealth is those with two prominent characteristics, namely feeling contended (qana'ah) and modest living ('iffah), because everyone has their own portion of the world. Moreover, Hamka suggests that an asset is only a means to get life goals. Essentially, the aim is to achieve moral perfection, as in the prophetic Mondial mission (itmamul akhlak). Therefore, to go through a world life filled with temptations and trials, spiritual piety, contentment, and modesty are important (Sutoyo, 2015). This 
is in line with Ulfah (2017) that according to Hamka, Sufism is not only defined as a solitary spirit, away from the world, but working is a must.

According to Hamka, true wealth is when people have contended with their needs and able to accept the good and bad reality. The concept of welfare in Islam is different from those in the western economic context. In the western perspective, welfare is measured by the individual satisfaction with various desires and the indulgence to consume everything by desiring to obtain material pleasures. Meanwhile, in Islam, welfare can be obtained from the ethical values of Islamic economics, such as the traits of qana'ah (contentment) to minimize human dependence on excessive material things. It also lies in spirituality (Razak \& Dali, 2012). Therefore, through the spirituality value in oneself, everyone becomes free from the various problems currently faced, such as excessive consumption patterns (israf or tabdzir), high lifestyles to compete or improve social status, and a high indebted culture that leads to inflation. This leads to the emergence of various negative social problems.

The results of this study have several contributions to the field of ethics of Islamic economics. Theoretically, this study contributes to provide wider perspective on the role of ethics in Islamic economics. In addition, the results of this study contribute to enriching the discourse of Islamic economic thought, especially in Islamic economic ethics and the role of ethics in business. Moreover, practically, this study contribute to enhance the implementation of Islamic ethics in economic activity to ensure that human economic-based activities are performed according to Islamic principles as stated by Hamka in his work of Tasawuf modern.

\section{Conclusion}

The purpose of this study is to determine the spiritual values of Islamic economics on Hamka's works entitled Tasawuf Modern. Thus, the spiritual values of Islamic economics in Hamka's works are listed in four points. First, the richest people are those that need the least. Second, true wealth is when people have contended with their needs and able to accept the reality of good and bad. Third, wealth can be good or bad, and wealth is a means to achieve the goals of human life. Fourth, humans need to be reasonable in the world to carry out the best possible good deeds. The result provides a useful contribution to enrich the discourse of Islamic economic thought, especially in Islamic economic ethics and the role of ethics in business activity. However, this study is limited in the scope which only analysed one of Hamka's works. Further research is suggested to study other works done by Indonesian Intellectuals related to Islamic economics thought and ethics to enrich the discourse of Islamic Economics in Indonesia. In addition, comparative studies are also suggested for future research on the topics of Islamic Economics ethics to reach a wider and more comprehensive perspective of 
Islamic Economics in relation to ethics in Economic activity.

\section{Authors' Declaration}

The authors made substantial contributions to the conception and design of the study. The authors took responsibility for data analysis, interpretation and discussion of results. The authors read and approved the final manuscript.

\section{ORCID}

Rahmad Hakim (D) http://orcid.org/0000-0002-0437-4187

Ahmad Fanani (D) http://orcid.org/0000-0001-7274-7718

\section{References}

Abdullah, H., Hafiz, A., Yusoff, M., \& Yakub, M. (2010). Islam dan keadilan sosial menurut pandangan Hamka dalam Tafsir al-Azhar: Tumpuan khusus kepada kepentingan zakat. Seminar Sarantau Islam E Kesejahteraan Sejagat, Anjuran Fakulti Usuluddin, Universiti Islam Sultan Sharif Ali, Brunei Darussalam, (pp. 1-10).

Abdullah, N. (2004). Konsep pemilikan di dalam Islam. Jurnal Usuluddin, 19, 21-32.

Abdurrahman, D. (2005). Israf dan Tabdzir: Konsepsi Etika-Religius dalam Al Qur'an dan Perspektif Materialisme-Konsumerisme. MIMBAR: Jurnal Sosial dan Pembangunan, 21(1), 65-80.

Almanar. (1993). Pemikiran Hamka Kajian Filsafat dan Tasawuf. Jakarta: Prima Aksara.

Ahmad, K., \& Hassan, A. (2000). Distributive justice: the Islamic perspective. Intellectual Discourse, 8(2), 159-172.

Akbar, A. (2012). Konsep kepemilikan dalam Islam. Jurnal Ushuluddin, 18(2), 124-140. http://dx.doi.org/10.24014/jush.v18i2.704

Andiko, T. (2018). Konsep Harta dan Pengelolaannya dalam Al-Qur'an. Al-Intaj: Jurnal Ekonomi dan Perbankan Syariah, 2(1), 57-50. http://dx.doi.org/10.29300/aij.v2i1.1110

Astiraga, H. (2018). Kedudukan harta dalam perspektif al quran dan hadis. Tahkim (Jurnal Peradaban dan Hukum Islam), 1(2), 106-120. https://doi.org/10.29313/tahkim.v1i2.4108

Aziz, A. R. (2002). Pemikiran Etika HAMKA. Malaysia: Utusan Publications \& Distributors.

Aziz, A., 2013. Etika Bisnis Perspektif Islam: Implementasi Etika Islami untuk Dunia Usaha. Bandung: CV ALFABETA.

Al Haq, M. A. \& Wahab, N. A. (2019). The Maqasid Al Shariah and the sustainability paradigm: Literature review and proposed mutual framework for asnaf development. Journal of Accounting and Finance in Emerging Economies, 5(2), 179196. https://doi.org/10.26710/jafee.v5i2.854

Alamad, S. (2017). A Historical Analysis of Financial Innovation in Islamic Economics and Finance from the Sixteenth Century to Present. In Financial Innovation and Engineering in Islamic Finance (pp. 65-89). Springer Netherlands.

Aliyu, S. A., \& Aini, A. N. (2017). Contemporary Islamic economic studies on Maqasid Shari'ah: a systematic literature review. Humanomics, 33(3), 315-334.

https://doi.org/10.1108/H-03-2017-0041 
Bungin, B. (2003). Analisis Data Kualitatif. Jakarta: Raja Grafindo Persada.

Chapra, M. U. (2008). The Islamic Vision of Development in The Light of Maqashid Syariah. IRTI-IDB.

Creswell, J. W. (2014). A concise introduction to mixed methods research. SAGE publications.

El-Ghazali, A. H., \& Series, I. E. T. (1994). Man is the basis of the Islamic strategy for economic development. Jeddah, Kingdom of Saudi Arabia: Islamic Research and Training Institute, Islamic Development Bank.

Faiz, K. (2016). Kata Israf dalam Al-Qur'an: Studi Komparatif Penafsiran Prof. Dr. Hamka dan Ibn Kathir: Surabaya: UIN Sunan Ampel Surabaya.

Hafas, F., Gunawan, A., \& Ratna, M. (2020). Ethics in Islamic economics: microfoundations for an ethical endogeneity. International Journal of Ethics and Systems, 36(3), 449-463. https://doi.org/10.1108/IJOES-03-2020-0032

Haq, S. G. (2013). Distribution of income and wealth in Islam. South East Asia Journal of Contemporary Business, Economics and Law, 2(2), 34-40.

Hajjar, M. \& Habib, F. (2019). Pioneer Islamic economics and banking experience in tsarist Russia. In Islamic Finance in Europe (pp. 257-269). Palgrave Macmillan.

Hakim, R. (2016). Membandingkan Konsep Pajak (Kharâj) Yahya bin Adam (758-818 H) dan Imam al-Mawardi (974-1058 H). TSAQAFAH, 12(1), 149-166. https://doi.org/10.21111/tsaqafah.v12i1.372

Hakim, R. (2018). Haji Abdul Malik Karim Amrullah (HAMKA) dan Ekonomi Islam: Studi Pada Karya Keadilan Sosial dalam Islam. Falah: Jurnal Ekonomi Syariah, 3(2), 58-70. https://doi.org/10.22219/jes.v3i2.7214

Hamka. (2015). Keadilan Sosial dalam Islam. Republika.

Hamka. (2018). Tasawuf Modern (X). Republika.

Hamka, R. (1983). Pribadi dan Martabat Buya Prof. Dr. Hamka. Jakarta: Pustaka Panjamas.

Haniff, Z. M., Kiat, L. T., \& Jing, Y. K. (2018). Principal-agent relationship issues in Islamic banks: a view of Islamic ethical system. International Journal of Islamic and Middle Eastern Finance and Management, 11(2), 297-311.

https://doi.org/10.1108/IMEFM-08-2017-0212

Hasan, Z. (2020). The Nature and Significance of Islamic Economics: Integrative Approach. Palgrave Macmillan.

Haris, A. (2010). ETIKA HAMKA; Konstruksi Etik Berbasis Rasional-Religius. Yogyakarta: LKIS PELANGI AKSARA.

Hidayat, U. T. (2015). Tafsir Al-azhar: Menyelami Kedalaman Tasawuf Hamka. Buletin Al-Turas, 21(1), 49-76. https://doi.org/10.15408/bat.v21i1.3826

Huda, N. (2006). Konsep Prilaku Konsumsi dalam Ekonomi Islami. Jurnal Ekonomi Yarsi, 3(3), 65-81.

Hidyayat, R., Hakim, I. N., Misriani, A., Murti, S., Syafril, S., \& Faisal, F. (2020). The Use of Poetic Narratives in Hamka's Qur'anic Exegesis Books, Tafsir Al Azhar. 492(RIICMuSSS 2019), 37-43. https://doi.org/10.2991/assehr.k.201113.008

Ihsan, N. H. (1997). Hamka (1908-1981): A Study of Some Aspect of His Sufi Thought 
.Master's thesis, International Islamic University Malaysia.

Ismail, N. B. (2017). The Qur'anic exegesis, reformism, and women in twentieth century Indonesia. Studia Islamika, 24(3), 469-501.

https://doi.org/10.15408/sdi.v24i3.5187

Iswandi, A. (2014). Maslahat Memelihara Harta Dalam Sistem Ekonomi Islam.

SALAM: Jurnal Sosial dan Budaya Syar-i, 1(1), 19-32.

https://doi.org/10.15408/sjsbs.v1i1.1522

Jan, S., Ullah, K., \& Asutay, M. (2015). Knowledge, work, and social welfare as Islamic socioeconomic development goals. Journal of Islamic Banking and Finance, 32(3), 919.

Khan, M. A. (1984). Islamic Economics: Nature and Need. Journal of Research in Islamic Economics, 1(2), 51-55.

Lukman, F. (2018). Digital hermeneutics and a new face of the Qur'an commentary:

The Qur'an in Indonesian's facebook. Al-Jami'ah, 56(1), 95-120.

https://doi.org/10.14421/ajis.2018.561.95-120

Masrur, M. (2018). Kontruksi Harta dalam Perspektif Hukum Ekonomi Syariah (Studi Analisis dalam al-Qur'an dan Hadis). Jurnal Hukum Islam, 15(1) 95-128.

Moleong, L. J. (2014). Metodologi Penelitian. Bandung: PT Remaja Rosdakarya Offset.

Md Isa, M. Y. A., \& Am, J. P. (2015). Penghayatan Fiqh Zakat Dalam Membangunkan Ummah Menurut Perspektif Hamka. In Proceeding of the International Conference on Masjid, Zakat dan Waqf (IMAF 2015) (pp. 1-2).

Nazir, M. (1988). Metode Penelitian. Jakarta: Ghalia Indonesia.

Najib, M. A. (2018). Epistemologi Tasawuf Modern Hamka. Dinamika Penelitian: Media Komunikasi Penelitian Sosial Keagamaan, 18(2), 303-324.

https://doi.org/10.21274/dinamika.2018.18.2.303-324

Naldo, J. (2016). Kritik Hamka terhadap Materialisme (Studi Filsafat Ketuhanan). Doctoral dissertation, UIN Sumatera Utara.

Nawaz, T. (2019). Exploring the Nexus Between Human Capital, Corporate Governance and Performance: Evidence from Islamic Banks. Journal of Business Ethics, 157(2), 567-587. https://doi.org/10.1007/s10551-017-3694-0

Naqvi, S. N. H.. (2003). Menggagas Ilmu Ekonomi Islam. Yogyakarta: Pustaka Pelajar.

Raco, J. R. (2003). Metode Penelitian Kualitatif: Jenis, Karakteristik dan Kegunaannya. Jakarta: Grasindo.

Rahman, A. (1996). Dotrin Ekonomi Islam, J.1, Terj. Nastangin. Yogyakarta: Dana Bhakti Wakaf.

Razak, N. A., Dali, S. Z. M., \& Pengurusan, F. E. D. (2012). Perbezaan analisis kepenggunaan menurut ekonomi konvensional dan ekonomi Islam. Prosiding PERKEM VII, 2, pp. 1461-1470.

Ridjaluddin, F. N. (2008). Mengungkap rahasia: tasauf versi Hamka. Pusat Kajian Islam, FAI Uhamka Jakarta.

Ridwan, M., \& Andriyanto, I. (2019). Sikap Boros: Dari Normatif Teks ke Praktik Keluarga Muslim. Al-Amwal: Jurnal Ekonomi dan Perbankan Syari'ah, 11(2), 273284.https://doi.org/10.24235/amwal.v11i2.4927

Rusdan, R. (2017). Konsep harta (al-maal) dalam perspektif ekonomi Islam. El-Hikam, 
10(2), 365-403.

Ryandono, M.N.H., (2009). Benarkah Bunga Haram? Perbandingan Sistem Bunga dengan Bagi Hasil \& Dampaknya pada Perekonomian. Surabaya: Amanah Pustaka.

Rouf, A. (2012). Dimensi tasawuf karya Hamka: analisis terhadap tafsir Al-Azhar. Doctoral dissertation, Jabatan al-Quran dan al-Hadith, Akademi Pengajian Islam, Universiti Malaya.

Rouf, A., Yakub, M., \& Yusoff, Z. M. (2013). Tafsir al-Azhar dan tasawuf menurut Hamka. Jurnal Usuluddin, 38(1), 1-30.

Sahin, A. (2018). Critical issues in Islamic education studies: Rethinking Islamic and Western liberal secular values of education. Religions, 9(11), 335-347. https://doi.org/10.3390/rel9110335

Setiani, R. (2011). Nilai-nilai pendidikan islam dalam buku tasawuf modern Buya Hamka. Doctoral dissertation, UIN Syarif Hidayatullah, Jakarta.

Silawati. (2015). Pemikiran Tasawuf Hamka dalam Kehidupan Modern. An-Nida': Jurnal Pemikiran Islam, 40(2), 118-125. http://dx.doi.org/10.24014/annida.v40i2.1502

Shinkafi, A. A., \& Ali, N. A. (2017). Contemporary Islamic economic studies on Maqasid Shari' ah: a systematic literature review. Humanomics, 33(3), 315-334. https://doi.org/10.1108/H-03-2017-0041

Subhi, M. R. I. (2012). Studi Analisis Pemikiran Hamka tentang Tasawuf Modern dan Pendidikan Islam. Doctoral dissertation, IAIN Walisongo.

Sutoyo. (2015). Tasawuf Hamka dan Rekonstruksi Spiritualitas Manusia Modern. ISLAMICA: Jurnal Studi Keislaman, 10(1), 108-136. https://doi.org/10.15642/islamica.2015.10.1.108-136

Syarifuddin, S. (2010). Pemikiran Buya Hamka Tentang Riba Dalam Tafsir Al-Azhar. Doctoral dissertation, Universitas Muhammadiyah Surakarta.

Tahir, S. (2017). Islamic economics and prospects for theoretical and empirical research. Journal of King Abdulaziz University: Islamic Economics, 30(1), 1-10.

Tellier, L.-N. (2019). The Great Ebb: Islam Out to Conquer the Great and the Asian Corridors. In Urban World History (pp. 131-163). Springer Netherlands.

Ulfah, N. M. (2017). Tasawuf Modern Studi Pemikiran Hamka (Haji Abdul Malik Karim Amrullah). Esoterik, 2(1), 95-109. https://doi.org/10.21043/esoterik.v2i1.1896

Watkins, J. S. (2020). Islamic Economics and Political Economy. In Islamic Finance and Global Capitalism (pp. 361-471). Palgrave Macmillan.

Zainuldin, M. H., Lui, T. K., \& Yii, K. J. (2018). Principal-agent relationship issues in Islamic banks: a view of Islamic ethical system. International Journal of Islamic and Middle Eastern Finance and Management, 11(2), 297-311.

https://doi.org/10.1108/IMEFM-08-2017-0212

Zaprulkhan, Z. (2013). Signifikansi revitalisasi tasawuf hamka dan said nursi bagi kehidupan masyarakat kontemporer. Jurnal THEOLOGIA, 24(2), 35-42.

Zulfa, F. (2015). Pengelolaan harta anak yatim dalam al-qur'an menurut M. Quraish Shihab dan Hamka. Doctoral dissertation, UIN Sunan Ampel Surabaya. 